\title{
The Journal of \\ Experimental Biology
}

E D I T E B Y

J. G R A Y

A S IST D B Y

J. Barcroft A. J. Clark J.B.S.Haldane J. S. Huxley W. H. Pearsall

S. C. Brooks F. A. E. Crew E. Newton Harvey M. H. Jacobs E. Ponder

R. Chambers W. O. Fenn L. T. Hogben C.F.A.Pantin J. T. Saunders

Vol. X, No. 3 Price 12s. 6d. net July, 1933

Subscription Price Per Volume 40s. Net

\section{CONTENTS}

Metabolic Changes Associated with Endocrine Activity and the Reproductive Cycle in Xenopus laevis. II. The Effect of Hypophysectomy on the Potassium Content of the Serum. By H. ZWARENSTEIN.

The Survival of the Spermatozoon in the Domesticated Fowl. By Arthur Walton and E. O. Whetham.

Phosphagen in the Electrical Organ of Torpedo. (With 3 Textfigures.) By ERnest Baldwin.

On the Cephalopod Phosphagen. (With 4 Text-figures.) By ERNEsT BALDWIN.

Is Cleavage Rate a Function of the Cytoplasm or of the Nucleus? By A. R. Moore.

Observations on the Nutrition of Maggots of Australian Blow-flies. By M. J. Mackerras and M. R. Freney.

The Effects of Hypophysectomy and Anterior Lobe Administration on the Skin and Thyroid of Triton cristatus. (With 2 Plates.) By A. Elizabeth Adams.

On the Control of the Level of Activity of the Animal Body: I. The Endocrine Control of Seasonal Variations of Activity in the Frog. (With 8 Text-figures.) By G. S. Carter.

The Temperature and Humidity Relations of the Cockroach (Blatta orientalis): I. Dessication. (With 5 Text-figures.) By D. L. Guns.

The Electrocardiogram of the Developing Chick. (With 2 Plates and 2 Text-figures.) By J. Yule Bogue.

Published for The Company of Biologists Limited by THE CAMBRIDGE UNIVERSITY PRESS

London: Fetter Lane, w.c. 4 


\section{TH E}

\section{QUARTERLY JOURNAL \\ OF}

\section{MICROSCOPICAL SCIENCE}

EDITOR :

EDWIN S. GOODRICH, M.A., LL.D., F.R.S.

Contents of No. 301-New Series

MEMOIRS.

F. H. Drummond. The Male Meiotic Phase in Five Species of Marsupials. (With Plates 1 and 2.)

James E. Lynch. The Miracidium of Heronimus chelydrae MacCallum. (With Plates 3 and 4 and 2 Text-figures.)

Dev RaJ Menta. On the Development of the Male Genitalia and the Efferent Genital Ducts in Lepidoptera. (With 18 Textfigures.)

N. Narasimhamurti. The Development of Ophiocoma nigra. (With Plates 5 and 6.)

Margot E. Metcalfe. Notes on the Structure and Development of the Female Genital System in Dasynoura leguminicola Lint. (Cecidomyidae-Diptera.) (With Plates 7 and 8, and 4 Text-figures.)

Karm Narayan Bahla, and Makund Behari Lal. On the Occurrence of 'Hepato-pancreatic Glands' in the Indian Earthworms of the Genus Eutyphoeus Mich. (With Plates 9 and 10.)

VISHWA NATH. Microchemical Tests for Fats, Lipoids, and Vacuoles, with special reference to Oogenesis.

Jyan L. Sutherland. Protozoa from Australian Termites. (With 9 Text-figures.)

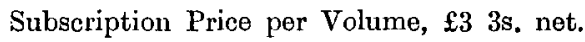

Single Parts $£ 11$ s. net.

OXFORD UNIVERSITY PRESS

AMEN HOUSE, LONDON, E.C. 4 
1. Observations and Experiments on Sex-Change in the European Oyster (O. edulis). Part III. On the Fate of Unspawned Ova. Part IV. ON the Change from Male to Female. By J. H. ORTON. With Text-Figures 1 (Part III) and 1-7 (Part IV)

2. Chenical Constituents of Biological Importance is the English Channel. Part III. June-December, 1932. Phosphate, Sillcate, Nitrate, Hydrogen Ion Concentration, with a Comparison with Wind Records. By L. H. N. COOPER. With 3 Figures in the Text .

3. The Rapid Estimation of the Copper Content of Sea-water. By W. R. G. ATKINS

4. The Use of Cuprous Oxime and other Rectifier Photo Cells in Submarine Photometry. By W. R. G. ATKNNS and H. H. POOLE. With 1 l'igure in the Text

5. The Seasonal Distribution of Macroplankton as shown by Catches in the 2-metre Stramin Ring-trawl in Off-shore Waters off Plymoeth. By F. S. RUSSELL

6. ON the BIology of Calanus finmarchicus. I. ReProduction and Seasonat Distribution in the Clyde Sea-Area during 1932. By A. G. NiCHOLls. With 4 Figures in the Text and Plates $I$ and $I I$.

7. ON the Biology of Calanus finmarchicus. II. Seasonal Variations in the Size of Calanus finmarchicus in the Clyde Sea-Area. By S. M. MARSHALL. With 8 Figures in the Text

8. ON the Biology of Calanus finmarchicus. III. Vertical Distribution and Diurfal Migration in the Clyde Sea-Area. By A. G. Nicholls. With 4 Figures in the Text

9. The Littoral Diatoms of the Liverpool and Port Erin Shores. By F. M. GHAZZAWI

10. ON the Marine Cladocera from the Northumbrian Platkton. By OLGA M. JORGENSEN. With 36 Figures in the Text and Diagrams $A, B$ and $C$.

11. Studies on the Moyogenea of Plymouth. Gastrocotyle trachuri v. Ben. AND Hesse, 1863. By E. IDRIS JONES. With 4 Figures in the Text .

12. Rhopalura granosa sp.nov., an Orthonectid Parasite of a Lavellibranch Heteranomia squamula L., with a Note on its Swimming Behaviodr. By D. ATKINS. With 4 Figures in the Text

13. ON the Rate of Diatom Growtr. By H. W. HaRVEY. With 3 Figures in. the Text

14. The Food Consumed by Shags and Cormorants around thf Shores of Cornwall (England). By G. A. STEVEN. With 2 Figures in the Text

15. The Magnesidu and other Inorganic Constituents of some Marine Invertebrates. By R. A. McCANCE and H. L. SHIPP. With 1 Figure in the Text.

16. Abrormal Eyes in Wild Gammarus zaddachi Sexton. By R. BASistNDalE. With 2 Figures in the Text

17. Notes on Some Copepoda from Plymodth. By ROBERT GURNEY. With 4 Figures in the Text

18. An Account of the Herring Investigations conducted at Plymodth DURING THE YeAhS FROM 1924-1933. By E. FORD. With 1 Chart and 10 Figures in the Text

19. Observations on the Reactions of Marine Plankton to Light. By.G. M. SPOONER. With 22 Figures in the Text .

20. Abstracts of Memoirs recording work done at the Plymotth Laboratory

21. Notices of Books.

22. REPORT OF COUNCII, FOR 1932

23. List of Annual Scbscriptions and Donations paid dering the Year, Ist Apri, 1932, to 31st March, 1933, with Balance Sheet and Income and ExpendTuRe ACCount (inset)

24. Lisi of Governors, Founders, and Members

\section{NOTICE.}

The Council of the Marine Biological Association wish it to be understood that they do not accept responsibility for statements published in this Journal excepting when those statcments are contained in an official report of the Council. 